\title{
Importance and future of individual markers for the ecosystem approach to fisheries
}

\author{
Jean-Marc Fromentin ${ }^{1}$, Bruno Ernande ${ }^{2,3}$, Ronan Fablet ${ }^{4,5}$ and Hélène de Pontual ${ }^{6}$ \\ 1 Ifremer, Centre de recherche halieutique méditerranéenne et tropicale, avenue Jean Monnet, BP 171, 34203 Sète Cedex, France \\ 2 Ifremer, Laboratoire ressources halieutiques, avenue du Général de Gaulle, BP 32, 14520 Port-en-Bessin, France \\ 3 Ecology and Evolution Program, International Institute for Applied Systems Analysis (IIASA), Schlossplatz 1, A-2361 Laxenburg, Austria \\ 4 Institut Telecom/Telecom Bretagne, CNRS UMR 3192 LabSTICC, Technopôle Brest-Iroise - CS 83818, 29238 Brest Cedex 3, France \\ 5 Université européenne de Bretagne, Institut national des sciences appliquées (INSA), 12 avenue Janvier, 35000 Rennes, France \\ ${ }^{6}$ Ifremer, Laboratoire de sclérochronologie des animaux aquatiques STH/LASAA, Z.I. Pointe du diable, BP 70, 29280 Plouzané, France
}

Received 14 November 2008; Accepted 11 April 2009

\begin{abstract}
The use of genetic, biochemical and electronic markers in population biology and ecology has been growing tremendously during the last two decades. The first part of this paper aims at reviewing the main principles and advances of these individual markers through a few key applications on exploited marine fish populations. The second part is more prospective and investigates some possibilities that could arise in the near future through: (i) the development of new markers, (ii) the combination of different markers and (iii) the combination of quantitative approaches -whether classical or new- with individual markers. It is finally stressed how crucial individual markers will be to unravel the biocomplexity of wild fish populations and the key role they should play in the implementation of the ecosystem approach to fisheries.
\end{abstract}

Key words: Genetic marker / Biochemical marker / Electronic tag / Otolith / Isotope / Population structure / Statistical and mechanistic model / Fisheries

\begin{abstract}
Résumé - L'utilisation de marqueurs génétiques, biochimiques et électroniques en biologie et en écologie a considérablement augmenté au cours des 20 dernières années. La première partie de cet article tente de synthétiser les principes et les progrès apportés par ces marqueurs individuels au travers de quelques applications marquantes menées sur les populations marines nectoniques exploitées. La seconde partie est plus prospective et examine quelques possibilités d'avenir : (i) le développement de nouveaux marqueurs, (ii) la combinaison de différents marqueurs et (iii) la combinaison d'approches quantitatives -classiques ou nouvelles- et de marqueurs individuels. Nous concluons sur l'apport crucial qu'auront les marqueurs individuels pour défricher la biocomplexité des populations de poissons sauvages et le rôle-clé qu'ils devraient jouer au sein de l'approche écosystémique des pêches.
\end{abstract}

\section{Introduction}

Fishery science has focused on scientific issues directly or indirectly related to stock assessment for more than half a century. Fisheries information (catch and fishing effort) was therefore the main if not the only source of data for fisheries scientists (Hilborn and Walters 1992). Since the 1990s, fisheries-independent information from scientific monitoring (e.g. acoustic surveys) has become crucial to quantitative stock assessment. More importantly, the general context of the world fisheries has considerably changed over the last two decades. Total catch of the world fisheries has indeed become stable at around 90 to 100 millions tonnes meanwhile reports of overexploitation on commercially-important stocks have proliferated (FAO 2004). This difficult context has therefore questioned the viability and sustainability of exploitation systems, from the viewpoint of both the resources and the human communities that depend on them (e.g. Pauly et al. 1998; Garcia and Grainger 2005; Hilborn et al. 2005). The causes of overexploitation (i.e. access rights, race for fish, overcapacity, subsidies, etc.) are nowadays widely acknowledged by the international scientific community and have led to key modifications in the perception of the dynamics of marine natural resources, their exploitation and governance (FAO 2002). Consequently, the scientific community has progressively moved from a standard stock-by-stock approach towards a more integrative approach which includes the various components of the marine ecosystems, called "Ecosystem Approach to Fisheries" (EAF, see e.g. Larkin 1996; Garcia et al. 2003; Browman et al. 2004; Turrell 2004; Fromentin et al. 2007). 
Since the early 1990s, the use of genetic, biochemical and electronic markers in population biology and ecology has grown tremendously because of the development of efficient and relatively inexpensive techniques. The EAF will probably make these natural and artificial individual markers more and more popular in fishery research. Such tools indeed allow the investigation of a wider range of novel and traditional issues than standard methods and provide a new and original perspective. The outputs of these new tools have already changed considerably our perception of several key ecological processes and have serious implications for management, as they often challenge current stock delimitations, connectivity between sub-populations, fish behaviour and responses to extrinsic forcing or reproduction success (e.g. Palsbøll et al. 1997; Gunn and Block 2001; Morin et al. 2004; Bekkevold et al. 2007; Rooker et al. 2008; Waples et al. 2008).

Despite the availability of a few reviews in some specific fields, such as marine fisheries genetics (see e.g. the stimulating article by Hauser and Carvalho 2008), there is, to our knowledge, no review of the use of different individual markers on marine populations. Because the EAF is by essence multidisciplinary, comparing and combining these different techniques is of interest when investigating exploited marine resources. Therefore, this article is an attempt to review some advances through a few applications and to investigate some possibilities that could arise in the near future through: (i) the development of new markers, (ii) the combination of different markers and (iii) the combination of classical and new quantitative approaches with individual markers.

\section{Advances in individual markers}

\subsection{Genetic markers}

Three main types of genetic markers are available currently (Fig. 1): mitochondrial DNA sequences (mtDNA), microsatellite loci ( $\mu$ SATs) and single nucleotide polymorphisms (SNPs). All mtDNA is inherited from the mother. $\mu$ SATs are portions of nuclear DNA consisting of short tandem repeat sequences of nucleotides (most $\mu$ SATs are based on 1 to 6 base pairs (bp) repeated units, Chistiakov et al. 2006). $\mu$ SATs are biparentally inherited, hyper-variable in length (variability in length representing different alleles) due to fast mutation rates, moderately abundant, and can be found every 5 to $50 \mathrm{kbp}$. SNPs are the most recently developed markers (early 2000s, although the technology has been around for longer). They correspond to locations in the nuclear DNA at which various nucleotides can be found in the population due to nucleotide substitutions resulting from point mutations, the DNA sequence being thus polymorphic (variable) at these locations. SNPs are biparentally inherited, extremely abundant (millions of SNPs exist and are potentially available) and can be found every 0.3 $1 \mathrm{kbp}$ (Morin et al. 2004).

Because of their high variability, which results from their rapid evolution, mtDNA and $\mu$ SATs have a strong discriminative power for any identification purpose, be it among populations, sub-populations or individuals. However, fast mutation rates $\left(\sim 10^{-2}\right.$ to $10^{-6}$ per locus per generation) may also lead to a high degree of homoplasy, i.e. the fact that genes are identical because of parallel evolution and not of coanscestry, thus imposing limitations on the interpretability of data analysis (Chistiakov et al. 2006). In contrast, SNPs do not suffer from homoplasy because of much lower mutation rates $\left(\sim 10^{-9}\right.$ per locus per generation) and are also much less variable. The resulting lack of discriminative power can be compensated by scoring more loci, which is not very demanding due to their abundance and the ease with which they can be identified (Brumfield et al. 2003). Notably, although mtDNA displays stronger drift at a single locus than nuclear markers, the power of the latter rapidly exceeds that of the former when considering multiple loci, because of the unlimited number of nuclear markers. These three types of genetic markers also differ in whether they lie in coding or non-coding parts of the genome. While $\mu$ SATs are mostly found in non-coding regions of the genome (85\% to $91 \%$ of $\mu$ SATs are non-coding in vertebrates, Chistiakov et al. 2006), mtDNA and SNPs can be easily found in both coding and non-coding parts of DNA. This difference has obvious implications in the choice of markers to study either neutral or adaptive processes. Note that the present paper does not investigate the use of genetic markers from the coding part of the genome which are, however, widely used for studies on natural selection and adaptive evolution, as we concentrate on issues related to the use of markers for identification purpose in the context of the EAF.

Beyond the plethoric field of phylogeny and phylogeography, neutral genetic markers, i.e. from the non-coding part of the genome, have been traditionally used to unravel population-level processes falling within three broad categories: (i) genetic variation, (ii) population abundance (and size) and (iii) population structure and migration (gene flow, Schwartz et al. 2007, Fig. 2). Genetic variation is generally assessed through allelic richness or diversity (total number of alleles or mean number of alleles per locus, $A$ ) and heterozygosity (the average number of heterozygous genotypes in the population, $H$, as a surrogate of the probability of finding two different alleles at a given locus when drawing them at random in the population). Sometimes it is also approached by considering the inbreeding coefficient $F_{\text {IS }}$ that estimates the decrease in heterozygosity due to inbreeding. These measures of genetic diversity allow evaluating genetic consequences of purely demographic processes (versus genetic adaptation to environmental conditions), such as reductions in population size or even population bottlenecks that lead to allele fixation by genetic drift (i.e. purely random processes versus adaptive processes). Monitoring genetic variability has obvious applied interest for biodiversity conservation. For instance, genetic diversity has been shown to be significantly higher in Mediterranean populations of white sea-bream located in a marine protected area (Pérez-Ruzafa et al. 2006). Temporal changes in neutral genetic variability can also be used as a fingerprint of fishing mortality. Several studies based on DNA extracted from archived samples of otoliths or scales have depicted a decrease in genetic diversity $(A$ and $H$ ) in New Zealand snapper (Hauser et al. 2002) and North sea cod (Hutchinson et al. $2003)$, as well as an increase in inbreeding $\left(F_{\text {IS }}\right)$ in North Sea plaice (Hoarau et al. 2005), during prolonged periods of overexploitation. 


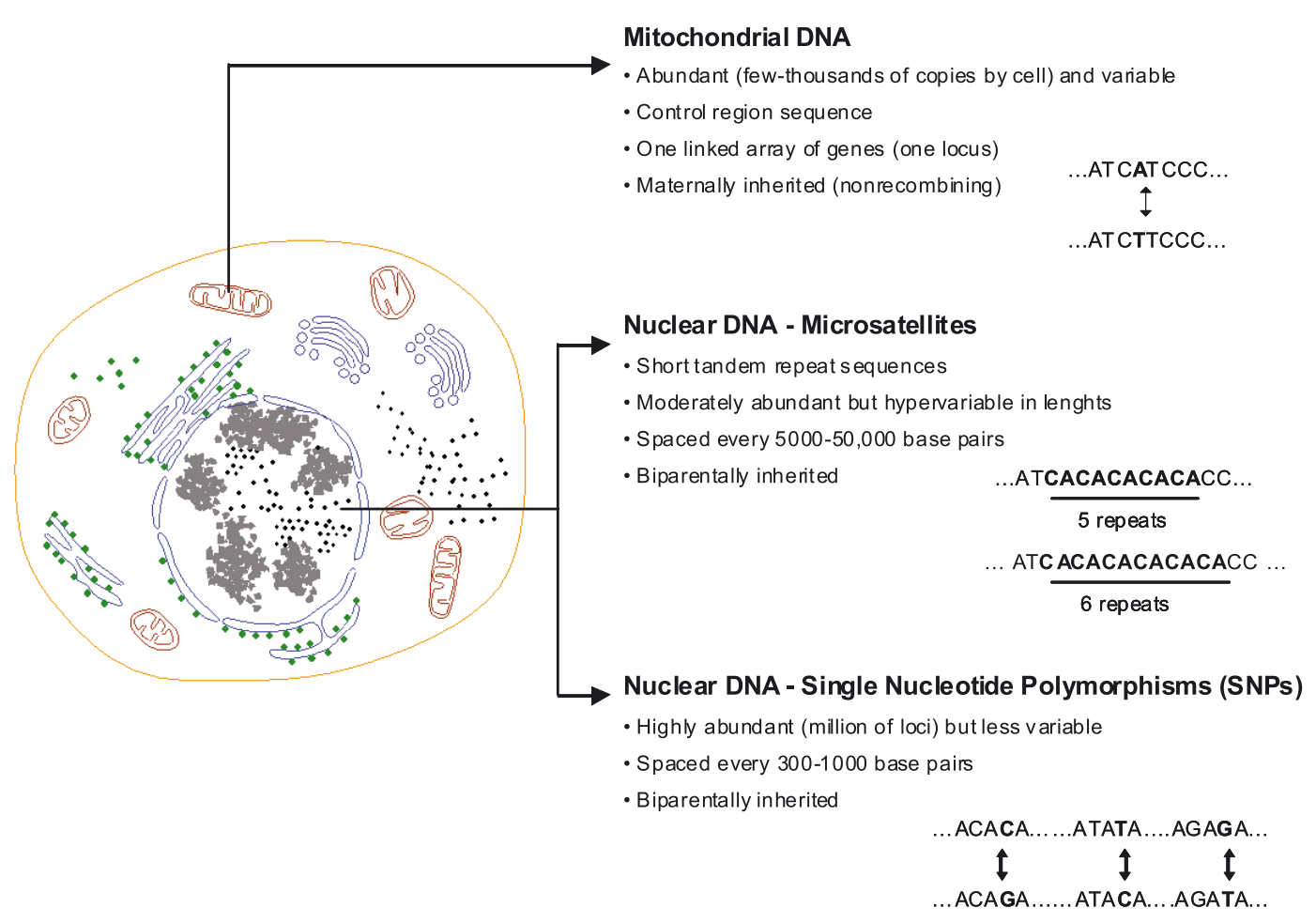

Fig. 1. Three main types of genetic markers (from Morin et al. 2004).

Regarding population abundance, neutral genetic markers can be used to estimate effective population size. The effective size of a population $(\mathrm{Ne})$ is the number of breeding individuals in an ideal theoretical population exhibiting the same magnitude of genetic drift as the actual population (Wright 1938; Hartl and Clark 1997). In other words, the effective population size evaluates the part of the population actually contributing to the next generation (Hauser and Carvalho 2008). Ne is therefore related to the reproductive success in the population and the size of the actual reproductive component, but it does not inform on the individual contributions (i.e. a given $\mathrm{Ne}$ can result from a moderate number of spawners with equal reproductive success or from a larger number of spawners with uneven reproductive success so that a few provide most of the recruits). Despite large census sizes, populations of marine fish actually appear to have relatively small effective population sizes that are 2-to-5 orders of magnitude lower than the census population sizes (N, Hauser et al. 2002; Turner et al. 2002; Hutchinson et al. 2003; Hoarau et al. 2005). High fecundity, variance in reproductive success, strong variation in year class strength and size-dependent fecundity are characteristics of marine fish, and more generally of many marine organisms; that may explain such discrepancy between effective and census size (Hedgecock 1994). Besides this general feature, effective population size allows following population dynamics (as it was done with salmon populations, see Waples 2002) and identifying events, such as population bottlenecks (i.e. drastic reduction in genetic variability generally related to strong population decline), as exemplified in lake trout and sockeye salmon (see Guinand and Scribner 2003; Ramstad et al. 2004). Effective population size, when estimated on a regular basis, could also be applied in stock assessment and management procedures as a complementary indicator to spawning stock biomass (Waples 2002; Waples et al. 2008). Note that some authors also advocated monitoring the expected heterozygosity $(\mathrm{He})$ or the allelic diversity to detect variation in population size (Schwartz et al. 2007).

Studies on population structure and connectivity rely on the estimation of genetic differentiation between population components. Several measures of genetic differentiation proposed by various authors are available: $F_{\mathrm{ST}}$ (Wright 1951), $G_{S T}$ (Nei 1973), $D$ (Nei 1978) and $R_{\mathrm{ST}}$ (Slatkin 1995), the first indicator being the most widely used. $F_{\mathrm{ST}}$ estimates the relative decrease in heterozygosity due to population sub-structure relative to the expected heterozygosity in an equivalent but panmictic population. $F_{\mathrm{ST}}$ thus provides a measure of genetic difference between sub-populations at a given point in time. Genetic differentiation allows studying population structuring by identifying partly reproductively isolated sub-populations as well as by estimating gene flow, a genetic surrogate of net migration flow, between these sub-populations. However, population structure is more difficult to detect for large populations such as marine species (e.g. Hauser and Carvalho 2008). Nonetheless, population structure on a relatively small geographical scale has been identified in North Sea, Baltic and Northeast Arctic cod (Hutchinson et al. 2001; Nielsen et al. 2001), North Pacific walleye pollock (O'Reilly et al. 2004), North Sea and Baltic Sea turbot (Nielsen et al. 2004) or Mediterranean sea bass (Lemaire et al. 2005), as well as gene flow or migration, like in the green turtle in the Southwest Indian Ocean (Bourjea et al. 2007). One of the most subtle examples is a recent study on Atlantic herring in the North Sea and adjacent waters (Ruzzante et al. 2006; Bekkevold et al. 2007). These works have shown that individuals originating from 


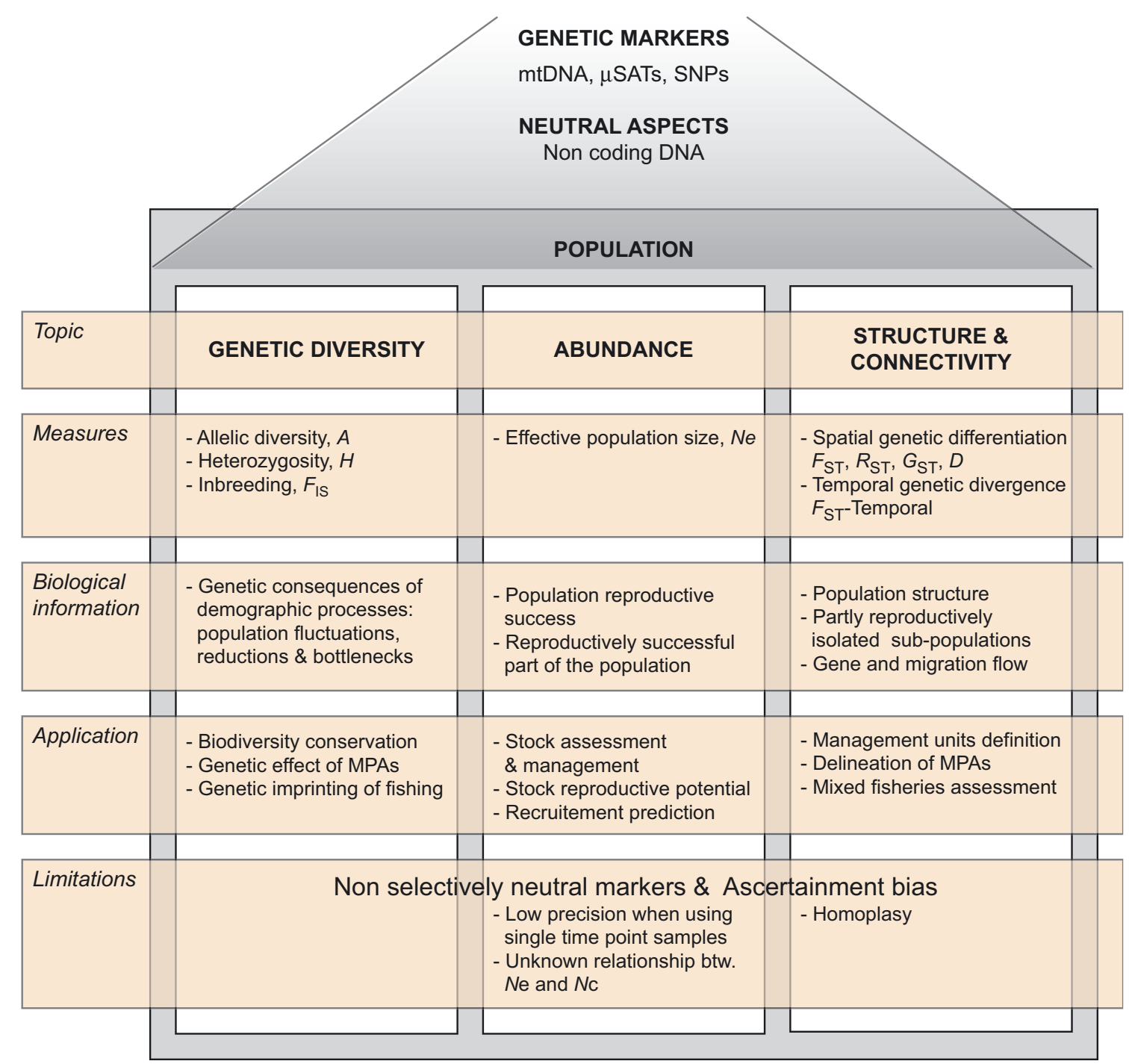

Fig. 2. Population level application of molecular markers. $A$ : allelic diversity, $H$ : heterozygosity, $F_{\text {IS }}$ : inbreeding coefficient, $N$ e: effective population size, $N$ c: census population size, $F_{\mathrm{ST}}, G_{\mathrm{ST}}, R_{\mathrm{ST}}$ : Wright's, Nei's and Slatkin's measures of genetic differentiation (Wright 1951 ; Nei 1973; Slatkin 1995), D: Nei's genetic distance (Nei 1978). MPA: Marine Protected Area. Ascertainment bias: bias due to non-random sampling of individuals and/or loci within individuals' genome. Homoplasy: identity of genes because of parallel evolution instead of coanscestry.

various spawning components, differing either in spawning location or in spawning season at the same location (i.e. sympatric spawning with seasonal segregation), are found on the same feeding and overwintering grounds. Such a population structure implies natal homing and spawning season fidelity (a feature that has been recently demonstrated with isotopic markers for another highly migratory pelagic fish, the Atlantic bluefin tuna, see below). From an applied point of view, information on population structure and connectivity can obviously be used to identify biologically meaningful management units (Palsbøll et al. 2007) as well as to delineate marine protected areas (Pérez-Ruzafa et al. 2006). It is also highly relevant in the assessment of mixed fisheries, i.e. fisheries targeting aggregations of individuals of a given species pertaining to different spawning components, such as in the North Sea cod (Nielsen et al. 2001) or North Sea herring (Bekkevold et al. 2007). Equivalent measures of temporal genetic differentiation between two points in time within a given population (generally called $F_{\text {Temporal }}$ ) can also be evaluated. This measure has been advocated as a sensitive indicator of population decline (Schwartz et al. 2007) and has been already used to track longterm changes in marine and aquatic populations, such as in brown trout (Østergaard et al. 2003).

\subsection{Otolith microchemistry}

The idea that the otolith chemical composition might be a valuable source of information emerged from progress achieved in using biocarbonates (corals, foraminifera, mollusc shells) as a proxy for current and past environments (e.g. Druffel 1997) because the chemical composition of these materials reflect that of the environment in which the organisms have lived. However, investigations for otolith chemical 


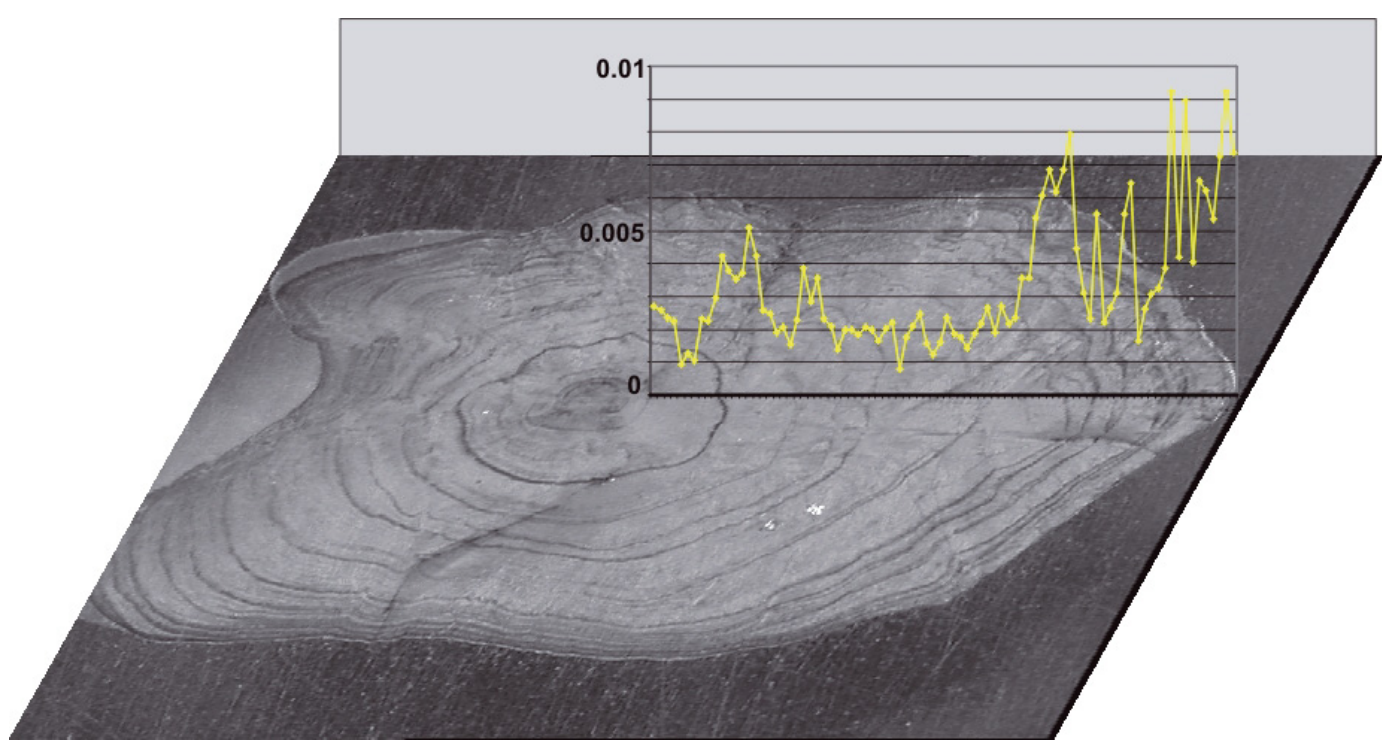

Fig. 3. Example of the temporal variation of a chemical marker (here $\mathrm{Sr} / \mathrm{Ca}$, see below) from the core (fish birth) to the edge (fish death) of an otolith of European eel. Photo P. Camoin and F. Daverat.

proxies do not relate so much to past environments (Ivany et al. 2000; Andrus et al. 2002) but to the fish itself. The scope of otolith chemical tracers covers questions such as, among others, individual life histories, population life traits, population structures, larval dispersal and population connectivity. Because they are metabolically inert (unlikely to be resorbed) and grow throughout the lifespan of the fish, otoliths are considered to be precise and continuous recorders of the physical environment experienced by the individuals (Campana 1999). As the accretion process follows a daily rhythm, otoliths can provide detailed chronologies whose temporal resolution depends on the analytical methodology used (Fig. 3). Although being particularly pure compared to other biogenic carbonates, otoliths offer various chemical proxies whose choice depends on the question to be addressed. An introduction to this field is presented below through a few illustrative examples (for detailed information on chemicals, applications, assumptions and methodologies, see Campana 1999; de Pontual and Geffen 2002; Elsdon et al. 2008).

Strontium $(\mathrm{Sr})$ and strontium/calcium $(\mathrm{Sr} / \mathrm{Ca})$ ratios have been mostly used because otolith takes up $\mathrm{Sr}$ in proportion to environmental $\mathrm{Sr} / \mathrm{Ca}$. In seawater, the latter is only slightly variable (de Villiers 1999) and is often much higher (8-10 folds) than in fresh water. As a consequence, the otolith $\mathrm{Sr} / \mathrm{Ca}$ ratio broadly acts as a proxy for ambient salinity and allows a distinction between contrasted environments, i.e. marine versus estuarine and freshwater. This property has largely been used for the analysis of migrations of diadromous species and the identification of population strategies and individual tactics. Salmonids and eels have been particularly studied. For instance, the analysis of $\mathrm{Sr} / \mathrm{Ca}$ signal demonstrated that eels have a facultative catadromy such that marine residency is an ecotype to be considered (Tsukamoto et al. 1998). This finding has been confirmed since then for the American, European and Japanese eels, which actually show a higher flexibility in habitat use than previously thought (Daverat et al. 2006). Aiming at filling the gap in the currently available statistical treatments of such data, Fablet et al. (2007) have recently proposed a robust, unsupervised and automatic method of detection of movements between given habitats. This approach allows to fully exploit the individual chronologies and to quantify the occurrences of the extracted tactics (Fig. 4).

It is worth noting that, whatever the indisputable interest of $\mathrm{Sr}$ and $\mathrm{Sr} / \mathrm{Ca}$ ratios, their use should be cautiously considered, as several factors such as temperature, ontogeny, stress, might be misleading (Kalish 1992; Secor 2000; de Pontual et al. 2003; Elsdon et al. 2008). Besides Sr elemental concentration, the Sr isotopes ratio $\left({ }^{87} \mathrm{Sr} /{ }^{86} \mathrm{Sr}\right)$ is particularly valuable for freshwater fish (Kennedy et al. 2000) because Sr isotopic signatures reflect the composition of continental waters which can vary greatly even among adjacent watersheds. Following $\mathrm{Sr}$, barium $(\mathrm{Ba})$ can substitute to $\mathrm{Ca}$ in the otolith mineral fraction, and otolith $\mathrm{Ba}$ concentration is known to be driven by its concentration in ambient water. Conversely to $\mathrm{Sr}$, freshwater is often enriched in $\mathrm{Ba}$ relative to the open ocean (Broecker and Peng 1982). This element, therefore presents a high potential for analysing movement patterns between coastal and continental habitats, particularly when used in conjunction with Sr (Elsdon and Gillanders 2006). Many other elements are linked to either the organic or mineral fractions of the otolith. The combinations of elements at trace or infratrace levels (often called "elemental fingerprints") have been widely used for a variety of applications, including populations structure and connectivity (Campana 1999; de Pontual et al. 2000; Gillanders 2002; Rooker et al. 2003).

Stable isotopes constitute another group of prevailing markers. In particular, it has been shown that otolith oxygen isotopes $\left(\delta^{18} \mathrm{O}\right)$ are deposited in thermodynamic equilibrium with those in ambient water whereas carbon isotopes are not (Kalish 1991; Hoie et al. 2004). As marine waters present a narrow range of variations in oxygen isotopic composition, otolith $\delta^{18} \mathrm{O}$ represents a valuable proxy of ambient temperature, allowing the reconstruction of individual thermal histories of marine species. Using this tracer in freshwater or in 


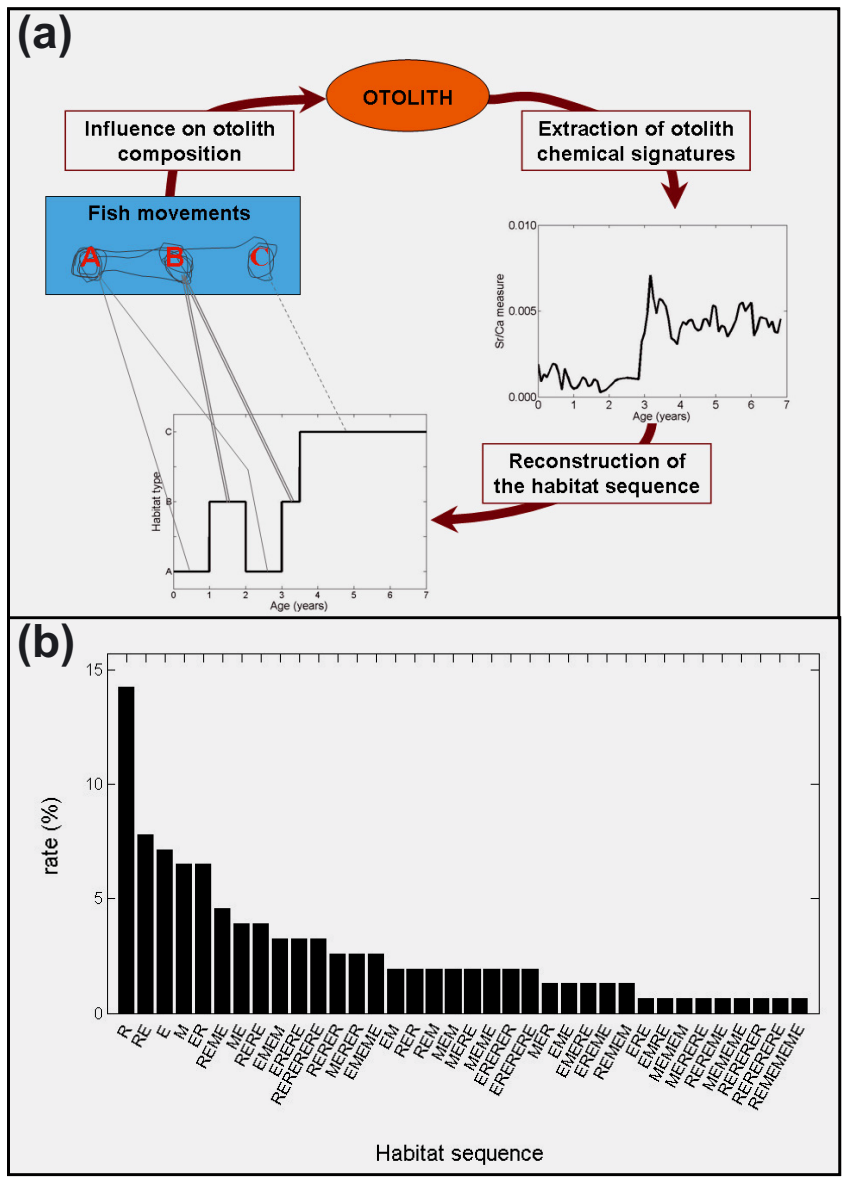

Fig. 4. (a) Principle of the reconstruction of the time habitat sequence of eels from the Gironde based on $\mathrm{Sr} / \mathrm{Ca}$ measurements spatially sampled on a standardized otolith growth axis; (b) Unsupervised analysis of the movement patterns: frequencies of the movement patterns extracted from the estimated habitat sequences using a hidden Markov model framework. Each habitat sequence is synthesized by the sequence of habitat changes ( $\mathrm{R}=$ river, $\mathrm{E}=$ estuarine, $\mathrm{M}=$ marine $)$ e.g. the habitat sequence EEEEEERRRRRRRR would be represented by the pattern ER (from Fablet et al. 2007).

coastal environments affected by freshwater run-off requires concurrent sampling of waters because the salinity and the water origin influence the oxygen isotopic composition. Conversely to oxygen, carbon isotope fractionation is affected by "vital effects" which encompass physiological process that potentially influence the preferential incorporation of isotopes. Thus, although partly determined by temperature, otolith $\delta^{13} \mathrm{C}$ also reflects metabolic effects (Hoie et al. 2003).

Current analytical limitations are still restricting the spatial (temporal) resolution of stable isotope records on otoliths. However, this approach has already provided valuable information. For instance, $\delta^{18} \mathrm{O}$ and $\delta^{13} \mathrm{C}$ have recently been used to investigate the reproductive strategy and the connectivity between the eastern and western stocks of Atlantic bluefin tuna (Rooker et al. 2008). Although only $\delta^{18} \mathrm{O}$ proved to be useful, this study tends to confirm natal homing for adults (i.e. individuals reproduce where they were born, i.e. in the Mediterranean Sea or in the Gulf of Mexico). Furthermore, East-toWest trans-Atlantic migrations were shown to be significant but size-dependent, with a high proportion of medium-size fish of eastern origin mixing with those of western origin along the US Atlantic coasts. Such information is critical for a sustainable exploitation of the resource, currently severely depleted, as it directly affects the efficiencies of management strategies and rebuilding plans (Fromentin and Powers 2005).

In conclusion, otolith chemical markers are precious tools for addressing numerous questions at both the individual and population scales. This field is strongly developing, and progress is still expected at different levels. Beside analytical improvements, a better understanding of the otolith chemical response to environmental and endogenous factors remains critical, and advances will depend upon both further experimental calibration studies as well as a better knowledge of the biomineralisation process (Allemand et al. 2007).

\subsection{Electronic tags}

Sea water is nearly opaque to electromagnetic radiation and it has been difficult therefore to track marine animals in situ. Marine biologists have been working for several decades to develop operational electronic devices aiming at studying behaviour, physiology, biology and ecology of these animals (Sibert 2001). This long-term effort led to two main categories of electronics tags: the acoustic telemetry and the archival ones. The former are small transmitters that are implanted either in the abdominal cavity of the fish, or attached externally. Those tags emit a signal at constant time intervals and are adapted to follow rapidly moving fish from a boat during a few days. This technique has been widely applied for two-tothree decades on salmonids, eels and many coastal shelf fish to understand spatial behaviour at small scales (see Arnold and Dewar 2001 for a review). More recently, it has been used to track tropical tunas to investigate their behaviour around fish aggregation devices (Dagorn et al. 2001). Acoustic tags can further be coupled with listening stations to study the behaviour of fish within a given location, such as a protected area, an estuary, a strait... This system has been applied to study the behaviour of post-smolt Atlantic salmon during their seaward migration (Lacroix and McCurdy 1996; Voegeli et al. 2001). Following these successful experiments in coastal waters, an ambitious USD168-million conservation project from Canada, "The Ocean Tracking Network (OTN)", has been set up to track in the near future thousands of marine animals using acoustic tags and acoustic receivers deployed in 14 ocean regions, mostly to understand the impact of climate changes on coastal and open-sea marine organisms (Fig. 5).

The second type of electronic tags, archival tags, can be assimilated to small computer data loggers that record and store information on time, swimming depth, water temperature and light levels. The different sensors sample at preset time intervals (fixed by the user or the manufacturer) and the data are stored in the hard memory of the tag. Internal archival tags are implanted in the abdominal cavity of the fish and can additionally store information on the body temperature but fish, however, must be recaptured. In that sense, archival tags provide fisheries-dependent information, as conventional tags. The high tag cost (up to USD 2 500) and low recapture rates (often $<10 \%$ ) have strongly limited their application and 


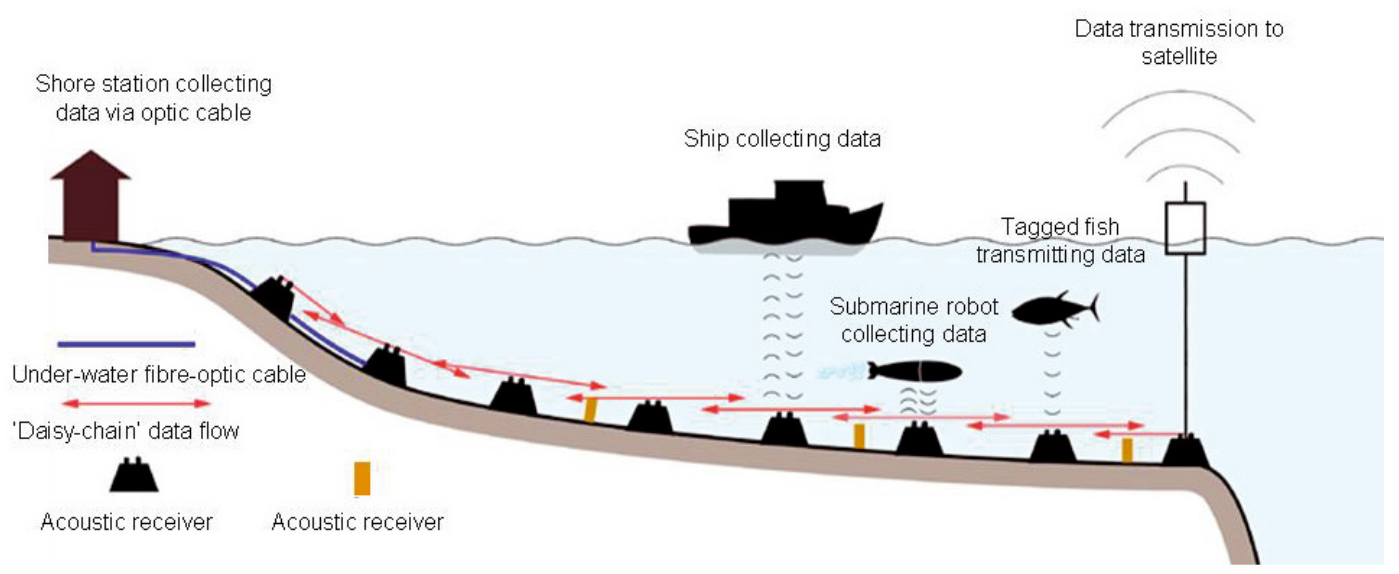

Fig. 5. Schematic representation of a fixed hydrophone array (or listening lines) for acoustic tag fixed on fish (or other marine animals) with radio or satellite transmission to shore stations (the present picture is taken from the Ocean Tracking Network, http://oceantrackingnetwork.org).

have further led to the development of new devices, called "pop-up" tag (Sibert 2001). Pop-up tags are attached to the back of the fish and detach themselves after a given preset time. First-generation pop-up tags (called "single point pop-up tags") do not store any data and simply transmit to a satellite the "pop-off" (detachment) location (Arnold and Dewar 2001). Second-generation pop-up tags, called "archival pop-up tags", include sensors of temperature, depth and light which are preprocessed by the tag/computer. These data are then transmitted to a satellite together with the end-point location when the tag reaches the surface after detachment. Although costly, such electronic devices have thus the great advantage of providing fisheries-independent information.

Archival and pop-up archival tags have been intensively deployed for a decade on large pelagics fish (tunas, marlins and sharks), demersal fish (mostly cod), flatfish as well as turtles and marine mammals. These experiments have deeply modified our understanding of the spatial dynamics and habitat preferences of these animals that, here again, appear to be more complex than previously thought (e.g. Holland et al. 2001; Gaspar et al. 2006; Prince and Goodyear 2006; Sibert et al. 2006; Sims et al. 2008). To illustrate these advances, Atlantic bluefin tuna is a good example, as this species has been particularly studied because of its high economic value and strong conservation and management concern (Fromentin and Ravier 2005; Porch 2005). Both archival and pop-up archival tagging have showed that bluefin tuna can sustain cold (down to $3{ }^{\circ} \mathrm{C}$ ) as well as warm (up to $30^{\circ} \mathrm{C}$ ) temperatures while maintaining stable internal body temperature (Block et al. 2001). Until recently, it was assumed that this species preferentially occupies the surface and subsurface waters of the coastal and opensea areas, but archival tagging showed that both juveniles and adults frequently dive to depth of 500 to $1000 \mathrm{~m}$ (Block et al. 2001; Brill et al. 2001). Similar behaviour has also been reported for southern bluefin tuna, bigeye tuna and swordfish and is generally related to foraging in deep scattering layers and/or to physiological constraints to cool the body temperature (Holland et al. 1992; Gunn and Block 2001; Musyl et al. 2003). These results make clear that bluefin tuna habitat (as those of bigeye tuna and swordfish) cannot be solely described in two dimensions.
More importantly for stock assessment and management purposes, electronic tagging brought key information on migration patterns, residency times as well as useful pieces of information about population structure and stock delimitation. Repetitive archival tagging experiments on bluefin tuna by US teams demonstrated that movement patterns vary considerably between individuals, years and areas (Lutcavage et al. 1999; Block et al. 2001). Furthermore, electronic tagging strongly challenges stocks delimitations currently used for bluefin tuna management, as higher rates of trans-Atlantic migration than suspected have been detected. Based on an impressive and unique tagging effort (772 electronic tags deployed from 1997 until 2005), Block et al. (2005) advocated for the twopopulations hypothesis, each with its distinct spawning area (i.e. the Mediterranean Sea and the Gulf of Mexico) but with an overlapping distribution on North Atlantic feeding grounds. Although this hypothesis is still debated (Carlsson et al. 2004; Fromentin 2009), archival tagging has been shown to be a powerful tool to propose original hypotheses about the spatial dynamics of highly migratory species that can be seldom studied with standard scientific surveys (such as acoustic surveys). Additionally, archival tagging information allows us to describe the behaviour of tuna in the water column, an information that can be valuable to estimate the probability of detection from a plane and thus to calibrate aerial surveys (Willis 2008) or refine standardized CPUE indices through habitatbased models (Bigelow and Maunder 2007).

The accumulation of tracking data from archival tagging further leads to a unique and highly valuable source of information to study and determine more precisely key habitats, as well as the impact of environmental changes on population and spatial dynamics (e.g. Kitagawa et al. 2006; Bestley et al. 2008). Pop-up archival tags deployed by Ifremer in 2006 and 2007, albeit strongly limited in number and time scale, provide an interesting illustration of this. This survey indicated that all the 10 medium-sized fish (young spawners of 30-50 kg) tagged and released 12 miles offshore Marseille rapidly left the Gulf of Lions. These fish, however, remained in the Western Mediterranean and did not migrate to adjacent areas, such as the Eastern Atlantic or the Central Mediterranean, within five months' time. The spatial analysis of these 
Kriging of 10 tracks from 2007 FR-PSAT

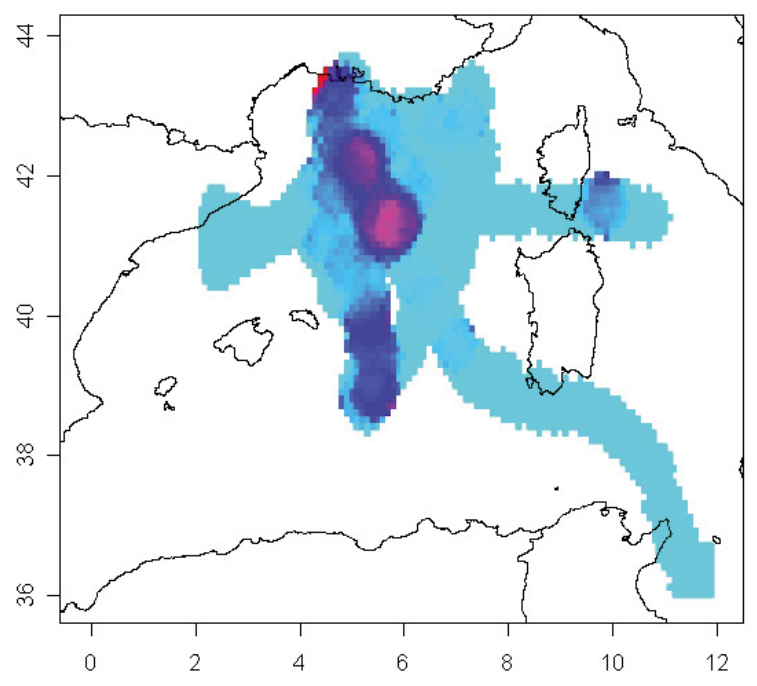

Fig. 6. Interpolation (i.e. kriging with a spheric model and moving neighbourhood) of 10 tracks obtained from pop-up archival tags deployed on bluefin tuna offshore Marseille.

tracks indicated a possible hotspot for foraging southeast of the Gulf of Lions (Fig. 6). This result remains preliminary because it is based on a small number of tags that did not exceed five months' time-at-liberty. However, it is generally in agreement with more extensive tagging surveys carried out on large bluefin tuna and which also showed residency time in the Mediterranean (de Metrio et al. 2001). If the tagging effort can be reinforced, such technique could provide a description of the foraging habitat of bluefin tuna in the Western Mediterranean and how this habitat changes through time. It would further give an estimation of migration rates between this basin and the Central Mediterranean as well as the East Atlantic and could serve to depict the main spawning migration routes of the young spawners.

By evidencing precisely spawning and foraging habitats and estimating migration rates between main areas, information from acoustic and archival tags is becoming crucial to establish appropriate time-area closures. The latter turns out to be a prevalent management tool within the ecosystem approach to fisheries and within various fisheries bodies (see Turrell 2004; FAO 2005).

\section{Prospects}

\subsection{New markers}

The three main types of individual markers are still evolving and their full potential is far to be achieved. For instance, new opportunities have come up through the application of neutral genetic markers to individual level issues. These applications can again be grouped in three categories: (i) individual assignment, (ii) relatedness and (iii) individual identification
(Fig. 7). Individual assignment consists in assigning individuals to a group of origin, which can correspond to different levels of aggregation (e.g. population, sub-population or family, thanks to similarities in alleles at neutral loci among individuals pertaining to the same group). Initially applied for species identification and traceability of fish products, assignment methods are starting to be applied at lower levels of aggregation, such as populations (Nielsen et al. 2001) or subpopulations (Bekkevold et al. 2007). This technique further presents obvious applications in the context of mixed fisheries to differentiate among contributions of various spawning components to the fisheries. Individual assignment gives access to information on individuals' origins in terms of population spawning component which, combined with knowledge about life history and ecology, may help in understanding natal homing, feeding migration or contribution of various nurseries to the adult population. Furthermore, in sufficiently closed populations such as marine mammals or salmonids, assignment of individuals to families (or parentage analysis) may be envisaged.

This links to the second category of application, namely relatedness. Two types of measure of relatedness of increasing precision are possible, using neutral markers (Blouin 2003). The pairwise coefficient of relatedness $r$ is the proportion of alleles that are shared by two individuals identical by descent as a surrogate of probability of gene-identity (Queller and Goodnight 1989; Ritland 1996; Lynch and Ritland 1999; Casteele et al. 2001; Wang 2002). Alternatively, individuals can be assigned to categories of relationship by evaluating the likelihood that an individual has the observed multilocus genotype given a known relationship category (parent, offspring, brotherhood, etc.) relative to the other individuals of the population. This so-called parentage analysis thus leads to the reconstruction of pedigrees (Goodnight and Queller 1999). While to our knowledge the first method has not been applied to wild fish, the second one has been used with success on bluegill sunfish (Neff 2001) and Pacific salmon (Bentzen et al. 2001). A recent analysis showed that the parentage analysis can provide more accurate estimates of connectivity in marine fish populations in situations of high gene flow (Saenz-Agudelo et al. 2009). Measures of individuals' relatedness have been proposed to infer quantitative genetic parameters of observed phenotypic traits in the wild, such as heritability (Ritland 2000), the fuel of evolution, thus permitting to estimate the potential for evolutionary adaptive changes of these traits. Although highly stimulating, for instance to investigate the adaptive response of fish to climate change, contaminants and exploitation, the use of measures of individuals relatedness from neutral genetic markers to infer quantitative genetic components require high precision estimates currently only reachable for rather small and closed populations.

Finally, neutral markers can be used to identify individuals just as if marked with artificial tags. So-called "genetic tagging" consists in a mark-recapture programme of free-ranging animals based on individual genetic markers that, in some cases, do not imply the capture or even the observation of these animals. For large marine top predators, for instance, a small biopsy can be extracted without manipulating and damaging the fish (for instance using soft harpoons) and is then 


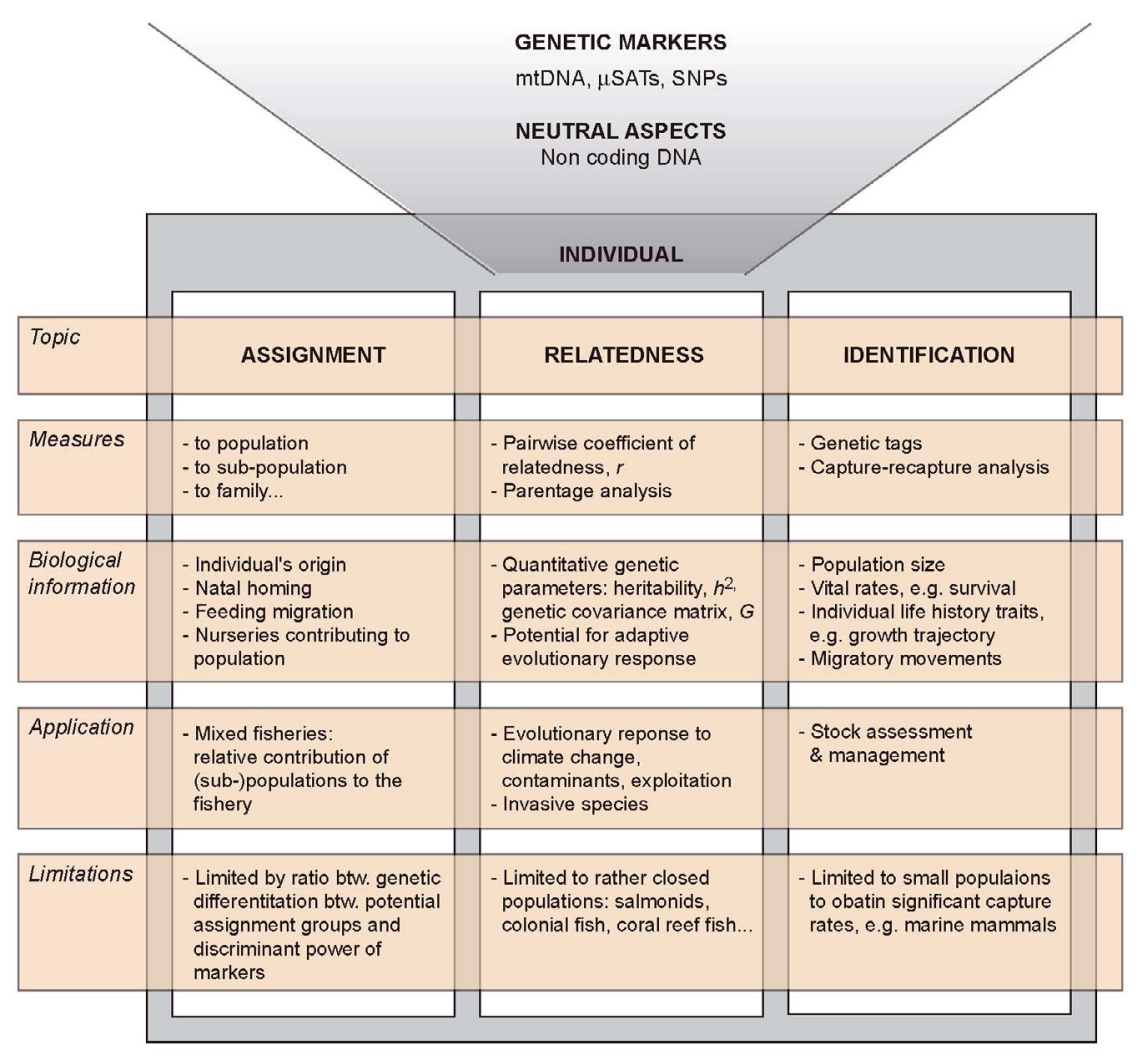

Fig. 7. Individual level application of molecular markers. $r$ : pairwise coefficient of relatedness, i.e. probability of gene-identity between two individuals due to coancestry; $h^{2}$ : heritability, i.e. the proportion of phenotypic variance for a given trait in the population due to genetic variability, determines the rate of evolution; $G$ : genetic covariance matrix, i.e. quantification of genetic variation within a population for a given trait and genetic co-variation between traits, determines evolutionary trajectories of phenotypic traits.

sent for identification of specific neutral markers that are precise enough to distinguish among individuals (Palsbøll 1999). Recapture operations are done by repeating the same procedure in a different area and at a different time, e.g. by collecting biopsies on landed fish. Mark and recapture genetic identifications are then compared and used within a statistical framework to estimate mortality and abundance (Lukacs and Burnham 2005; Miller et al. 2005; Petit and Valiere 2006). Genetic tagging thus avoids two crucial problems encountered in conventional tagging operations: i) post-release mortality and ii) inaccurate estimate of the reporting rate. Another advantage is the use this genetic information for population structure studies (see above). This technique implies high sampling rate and has therefore been applied with success on rather small/closed populations, such as marine mammals (humpback whale) and terrestrial mammal populations (bear, marte, see Palsbøll et al. 1997; Woods et al. 1999; Mowat and Paetkau 2002). However, it could be of interest for species for which catch and effort data are incomplete, strongly biased or for species for which stock structure and migration patterns are unclear. This technique is currently tested for several marine exploited fish species, such as sebaste spp. from the Northeast Pacific coasts, seabass and southern bluefin tuna. For the latter (a highly valuable species which has been strongly overfished for more than two decades), the aim is to estimate the absolute spawning stock size using the genetic identification of parent-offspring matches in samples from Indonesia and the Great Australian Bight (Bravington and Grewe 2007). The great advantage of this approach is to assess the stock size using fisheries-independent information thus avoiding the use of fisheries data (i.e., catch or Catch-Per-Unit-Effort) which are known to be biased and subject to severe interpretation problems for this species (see CCSBT 2008).

Finally, although this paper is restricted to the use of neutral genetic markers, it is worth mentioning the explosion of studies on gene expression patterns over the last decade (see Goetz and MacKenzie 2008 for a recent review). The growing interest in this topic has been triggered by the development of DNA microarrays and the improvement of sequencing methods. DNA microarray is a new technology to characterize gene expression profiles. It has been mostly used to study physiological, developmental or cellular processes, especially to investigate the regulation of gene expression as a function of environmental conditions and/or developmental stages in controlled conditions. Such technique can now be used to address ecological, evolutionary and environmental questions, including the variability of gene expression in natural fish populations, ecotypic diversity, or local adaptation due to natural selection or adaptive responses to human impacts. 


\subsection{Combining different individual markers}

Genetic tagging represents a combination of neutral genetic markers with the classical mark-recapture statistical theory (e.g. Lebreton et al. 1992; Pollock 2000). Additionally, it might be of interest to combine several individual markers to circumvent theoretical and/or practical limitations of a given marker. Concerning electronic tagging, a new "revolution" could come from the combination of the acoustic and archival technology. Two prototypes are currently under development, i.e. the "chat tag" and the "business card tag" (Dagorn and Holland, pers. comm.). The former is an acoustic tag that can record and store information on depth, temperature and light which is transmitted to listening stations when the tagged fish swim close by. The latter is a two-way receiver tag that identifies and stores acoustic signals sent by other acoustic tags. These new technologies (that could be further combined) thus have a great potential for the supervision and monitoring of MPAs and could improve greatly the estimation of survival rates of fish populations displaying known migration routes, such as salmon and eel.

As we already stressed, a growing and impressive effort has been made during the last two decades to develop and apply genetic, biochemical and electronic markers to address a wide range of questions in fisheries science. Consequently, most of these applications have used individual markers independently from one another. However, all individual markers have intrinsic limitations. Electronic tags were chiefly used to describe migration patterns and spatial distribution. They can further help in better understanding reproduction strategy or population structure, but they cannot solely reach validated and firm conclusions on these issues as the natal origins of the tagged fish remain unknown. In contrast, microchemistry analyses and neutral genetic markers can allow to distinguish between different spawning sub-populations possibly related to different spawning grounds (i.e., origins of the fish), but provide limited understanding of the real-time spatial dynamics and potential levels of mixing of fish living in a rather homogeneous environment. Such limitation could, however, be circumvented by using these powerful techniques in parallel (i.e. on the same individuals), so that we may obtain information about the migration pattern of a given fish together with its place of birth, heredity and reproductive potential. For instance, it is reasonable to postulate that individuals of a given sub-population are not only characterised by a given spatial distribution, but also by particular physiological (e.g. different tolerance to temperature or salinity), biological (e.g. distinct growth rates or age-at-maturity) and ecological (e.g. specific migration patterns and spawning sites) features. On large migratory species, such as temperate and tropical tuna, electronic tagging, genetic and isotopic analyses have been widely used (see above), but always independently. There would be a significant gain to use all these techniques simultaneously, i.e. by deploying electronic tags and getting biochemical and/or genetic information from a non-invasive biopsy on the same fish which would enable scientists to obtain information on population structure as well as information on key biological/ecological processes (e.g. identification of the spawning and foraging sites, detection of natal homing, migration patterns and connectivity between main areas). Therefore, it might be possible to investigate residency/migratory behaviour among different sub-populations as well as the level of adaptation of some key biological processes to local/regional environments. By combining individual markers, it would be thus possible to obtain complementary information, but also to get higher validation and precision, as genetic, chemical and electronic markers display different types of limitation and performance.

\subsection{Combining markers and models}

Given the differences in the nature of the information provided by each type of markers (mostly qualitative from genetic markers versus quantitative from otoliths and electronic tags, or temporal from electronic tag or otolith transects versus mostly spatial from genetic markers), appropriate models and inference methods have to be considered. Two complementary approaches are particularly appealing to address this issue: the mechanistic bio-energetic models and the Bayesian state-space models.

State-space models (within a Bayesian framework or not) aim at reconstructing an unobserved state sequence (i.e. the underlying and not directly observed biological/ecological process of interest) from an observed series of markers. These models imply two main components. The first one is a dynamic model characterizing the dynamics of the state sequence. The state sequence may involve two types of state variables: continuous state variables (e.g. geographical positions) and discrete state variables (e.g. geographical areas). This is of particular interest for the combination of multiple individual markers which are related to different state variables both continuous and discrete (e.g. natal origin, metabolic regime, geographical zone, geographical positions). For instance, when the state sequence corresponds to geographical positions, this dynamic model is typically a Brownian motion (e.g. Sibert and Fournier 2001). For discrete state variables, such as geographical zones, the dynamic model states the transition likelihood from one area to another (e.g. Fablet et al. 2007). The second component is a probabilistic observation-driven model which relates the state variables to the observations (from the markers). The definition of the latter observation-driven component is generally the most critical aspect for the efficiency of a state-space model. It may be derived from additional information. In the case of the archival tags, the geographical positions are estimated from the light records (sunset giving the longitude and length, the day the latitude). However, these estimates remain largely uncertain, but can be greatly improved by introducing constraints on temperature, so that the temperature recorded by the tag at the estimated daily position matches the temperature field given by oceanic models (Royer et al. 2005; Nielsen and Sibert 2007). Such supplementary information or a priori models are not always available and have often to be inferred from the data itself. For instance, in the study on the individual chronologies of habitat use of European eel (either river, estuary, or coastal) estimated from the $\mathrm{Sr} / \mathrm{Ca}$ measures acquired along an otolith growth axis, the model of $\mathrm{Sr} / \mathrm{Ca}$ signatures in the different geographical zones was directly derived from the data (Fablet et al. 2007). This is one important contribution of the state-space models which were initially introduced with 
linear models (i.e. the well known Kalman filter which was widely used by oceanographers for several decades; Kalman 1960). New approaches, such as the particle filter (which are non-linear models), have been recently developed and have been successfully applied to reconstruct the track of a fish from archival tags data (Royer et al. 2005).

Regarding the latter observation-driven model, a challenge is to relate, within a unified framework, the physiological state variables (e.g. the metabolic regimes) to the observations of the marker(s). Some benefit in this respect may be gained from the advances in modelling individual bio-energetic dynamics, especially the Dynamic Energy Budget theory (DEB, Kooijman 2000). A joint model relating otolith growth and opacity to fish metabolism and environmental factors (temperature and feeding conditions) is currently under development (Fablet et al., unpublished). This model describes the formation of the otolith as a DEB product, i.e. as resulting from metabolic fluxes, namely dissipation and somatic growth fluxes. An additional temperature-specific effect accounts for the known effect of temperature on otolith growth (more specifically on the rate of the precipitation of aragonitic calcium carbonate, see Romanek and Gauldie 1996). Validated for different cod stocks, this model permits the appreciation of differences in otolith growth and opacity patterns as a result of differences in the environments and life histories experienced by the fish. From a computational point of view, this model resorts to a continuous dynamic model specified by ordinary differential equations that describe the fish and otolith state variables. The potential of this model for the reconstruction of individual life history traits that has also been demonstrated using optimal control theory techniques (Lions 1971) thus provides the basis for integrating otolith chemical markers (especially trace elements and stable isotopes) with key physiological and biological processes. The application of such model to the fusion of multiple individual markers then presents a great potential. It could lead to distinguish different types of state variables, such as:

- Phenotype, the stock and/or the natal origin which could be viewed as hyper-parameters of the bio-energetic model, defining different initial parameterization of the models;

- Metabolic activity, e.g. swimming speed and the migratory behaviour which could act as modulation factors for some model parameters;

- Somatic maintenance rate and variables which are predicted by the bio-energetic model such as somatic growth and otolith markers.

Hence, this type of model would provide a mathematicallyand biologically-sound fusion approach.

\section{Conclusion}

Individual markers have been shown to be very useful and successful in a wide range of issues of fisheries research, especially for investigating population structure, individual behaviour, migration patterns, reproductive biology and strategy, natal origin, nurseries contribution, habitat uses and responses to extrinsic/environmental forcing. It results that individual markers have already considerably modified (and most often highly complexified) our perception of several key physiological, biological and ecological processes in exploited fish populations. Because of this impressive progress, fisheries scientists can understand more precisely the complex interactions between fish and environment and thus the biocomplexity of wild fish populations (Hilborn et al. 2003; Ruzzante et al. 2006).

Future developments through new markers, the combination of different markers and the emergence of new quantitative approaches further offer new promising roads to better understand biological processes and to assess quantitatively wild populations. Individual markers are thus not limited to academic research. They already have critical implications for management of exploited fish, as these tools have challenged stock delimitations and connectivity, habitat uses as well as impact of fishing on wild populations. New techniques (such as the systems of listening stations) and new markers appear promising also for the establishment and the monitoring of marine protected areas and thus should be key tools in the implementation of the ecosystem approach to the fisheries.

\section{References}

Allemand D., Mayer Gostan N., de Pontual H., Boeuf G., Payan P., 2007, Fish otolith calcification in relation to endolymph chemistry. In: Bäuerlein E. (Ed.) Handbook of Biomineralization. Wiley-VCH, Weinheim, pp. 291-308.

Andrus C.F.T., Crowe D.E., Sandweiss D.H., Reitz E.J., Romanek C.S., 2002, Otolith $\delta^{18} \mathrm{O}$ record of mid-Holocene sea surface temperatures in Peru. Science 295, 1508-1511.

Arnold G.P., Dewar H., 2001, Electronic tags in marine fisheries research: a 30-year perspective. In: Sibert J.R. Nielsen J.L. (Eds.) Electronic tagging and tracking in marine fisheries. Kluwer Academic Publishers, Dordrecht, pp. 7-64.

Bekkevold D., Clausen L.A.W., Mariani S., André C., Christensen T.B., Mosegaard H., 2007, Divergent origins of sympatric herring population components determined using genetic mixture analysis. Mar. Ecol. Prog. Ser. 337, 187-196.

Bentzen P., Olsen J.B., McLean J.E., Seamons T.R., Quinn T.P., 2001, Kinship analysis of Pacific salmon: Insights into mating, homing and timing of reproduction. J. Hered. 92, 127-136.

Bestley S., Patterson T.A., Hindell M.A., Gunn J.S., 2008, Feeding ecology of wild migratory tunas revealed by archival tag records of visceral warming. J. Anim. Ecol.77, 1223-1233.

Bigelow K.A., Maunder M.N., 2007, Does habitat or depth influence catch rates of pelagic species? Can. J. Fish. Aquat. Sci. 64, 15811594.

Block B.A., Dewar H., Blackwell S.B., Williams T.D., Prince E.D., Farwell C.J., Boustany A., Teo S.L.H., Seitz A., Walli A., Fudge D., 2001, Migratory movements, depth preferences and thermal biology of Atlantic bluefin tuna. Science 293, 1310-1314.

Block B.A., Teo S.L.H., Walli A., Boustany A., Stokesbury M.J., Farwell C.J., Weng K.C., Dewar H., Williams T.D., 2005, Electronic tagging and population structure of Atlantic bluefin tuna. Nature 434, 1121-1127.

Blouin M.S., 2003, DNA-based methods for pedigree reconstruction and kinship analysis in natural populations. Trends Ecol. Evol. 18, 503-511.

Bourjea J., Lapègue S., Gagnevin L., Broderick D., Mortimer J.A., Ciccione S., Roos D., Taquet C., Grizel H.M.E., 2007, Phylogeography of the green turtle Chelonia mydas in the Southwest Indian Ocean. Mol. Ecol. 16, 175-186. 
Bravington M., Grewe P., 2007, A method for estimating the absolute spawning stock size of SBT using close-kin genetics. CCSBT 8th Meeting of the Stock Assessment Group and CCSBT 12th Meeting of the Extended Scientific Committee.

Brill R.W., Lutcavage M.E., Metzger G., Bushnell P.G., Arendt M., Lucy J., Watson C., Foley D., 2001, Horizontal and vertical movements of juvenile bluefin tuna (Thunnus thynnus) in relation to oceanographic conditions of the western North Atlantic determined with ultrasonic telemetry. Fish. Bull. 100, 155-167.

Broecker W.S., Peng T.-H., 1982, Tracers in the sea. Lamont-Doherty Geological Observatory.

Browman H.I., Cury P., Hilborn R., Jennings S., Lotze H.K., Mace P.M., Murawski S.A., Pauly D., Sissenwine M., Stergiou K.I., Zeller D., 2004, Theme Section: Perspectives on ecosystembased approaches to the management of marine resources. Mar. Ecol. Prog. Ser. 274, 269-303.

Brumfield R.T., Beerli P., Nickerson D.A., Edwards S.V., 2003, The utility of single nucleotide polymorphisms in inferences of population history. Trends Ecol. Evol. 18, 249-256.

Campana S.E., 1999, Chemistry and composition of fish otoliths: pathways, mechanisms and applications. Mar. Ecol. Prog. Ser. 188, 263-297.

Carlsson J., McDowell J.R., Diaz-Jaimes P., Carlsson J.E.L., Boles S.B., Gold J.R., Graves J.E., 2004, Microsatellite and mitochondrial DNA analyses of Atlantic bluefin tuna (Thunnus thynnus thynnus) population structure in the Mediterranean Sea. Mol. Ecol. 13, 3345-3356.

Casteele T.V.D., Galbusera P., Matthysen E., 2001, A comparison of microsatellite-based pairwise relatedness estimators. Mol. Ecol. 10, 1539-1549.

CCSBT, 2008, Report of the 9th Meeting of the Stock Assessment Group and 5th Meeting of the Management Procedure Workshop. Commission for the Conservation of Southern Bluefin Tuna, Rotorua, New Zealand.

Chistiakov D.A., Hellemans B., Volckaert F.A., 2006, Microsatellites and their genomic distribution evolution function and applications: A review with special reference to fish genetics. Aquaculture 255, 1-29.

Dagorn L., Bertrand A., Bach P., Petit M., Josse E., 2001, Improving our understanding of tropical tuna movements from small to large scales. In: Sibert J.R. Nielsen J.L. (Eds.) Electronic tagging and tracking in marine fisheries. Kluwer Academic Publishers Dordrecht, pp. 369-384.

Daverat F., Limburg K.E., Thibault I., Shiao J.C., Dodson J.J., Caron F.O., Tzeng W.N., Iizuka Y., Wickstrom H., 2006, Phenotypic plasticity of habitat use by three temperate eel species Anguilla anguilla A. japonica and A. rostrata. Mar. Ecol. Prog. Ser. 308, 231-241.

De Metrio G., Arnold G.P., de la Serna J.M., Yannopoulos C., Megalofonou P., Buckley A.A., Pappalepore M., 2001. Further results of tagging Mediterrranean bluefin tuna with pop-up satellite detected tags. Col. Vol. Sci. Pap. ICCAT 52, 773-783.

de Pontual H., Geffen A.J., 2002, Otolith microchemistry. In: Panfili J., Pontual H. de, Troadec H., Wright P.J. (Eds.). Manual of fish sclerochronolgy. Ifremer- IRD Brest, pp. 245-302.

de Pontual H., Lagardere F., Amara R. Bohn M. Ogor A., 2003, Influence of ontogenetic and environmental changes in the otolith microchemistry of juvenile sole (Solea solea). J. Sea Res. 50, 199-210.

de Pontual H., Lagardère F., Troadec H., Batel A., Desaunay Y., Koutsikopoulos C., 2000, Otoliths imprinting of sole (Solea solea) from the Bay of Biscay: a tool to discriminate individuals from nursery origins? Oceanol. Acta 23, 497-513. de Villiers S., 1999, Seawater strontium and $\mathrm{Sr} / \mathrm{Ca}$ variability in the Atlantic and Pacific oceans. Earth Planet Sci. Lett. 171, 623-634.

Druffel E.R.M., 1997. Geochemistry of corals: Proxies of past ocean chemistry ocean circulation and climate. Proc. Nat. Acad. Sci. US 94, 8354-8361.

Elsdon T.S., Gillanders B.M., 2006, Temporal variability in strontium, calcium, barium and manganese in estuaries: Implications for reconstructing environmental histories of fish from chemicals in calcified structures. Estuar. Coast. Shelf Sci. 66, 147-156.

Elsdon T.S., Wells B.K., Campana S.E., Gillanders B.M., Jones C.M., Limburg K.E., Secor D.H., Thorrold S.R., Walther B.D., 2008, Otolith chemistry to describe movements and life-history parameters of fishes: Hypotheses assumptions limitations and inferences. Oceanogr. Mar. Biol. Ann. Rev. 46.

Fablet R., Daverat F., de Pontual H., 2007, Unsupervised Bayesian reconstruction of individual life histories from otolith signatures: case study of $\mathrm{Sr}: \mathrm{Ca}$ transects of European eel (Anguilla anguilla) otoliths. Can. J. Fish. Aquat. Sci. 64, 152165.

FAO, 2002, Report and documentation of the International Workshop on Factors Contributing to Unsustainability and Overexploitation in Fisheries. Bangkok, 4-8 February 2002. FAO Fish. Rep. No. 672.

FAO, 2004, The state of the world fisheries and aquaculture 2004.

FAO, 2005, Putting into practice the ecosystem approach to fisheries.

Fromentin J.-M., 2009, Lessons from the past: investigating historical data from bluefin tuna fisheries. Fish Fish. 10, 197-216.

Fromentin J.-M., Powers J.E., 2005, Atlantic bluefin tuna: population dynamics, ecology, fisheries and management. Fish Fish. 6, 281306.

Fromentin J.-M., Ravier C., 2005, The East Atlantic and Mediterranean bluefin tuna stock: looking for sustainability in a context of large uncertainties and strong political pressures. Bull. Mar. Sci. 76, 353-362.

Fromentin J.-M., Planque B., Thébaud O., 2007, L'approche écosystémique des pêches: quelles priorités pour la recherche ? The ecosystem approach to fisheries: What are the research priorities? Ifremer Report.

Garcia S., Grainger J.R., 2005, Gloom and doom? The future of marine capture fisheries. Phil. Trans. R. Soc. B 360, 21-46.

Garcia, S.M., Zerbi, A., Aliaume, C., Do Chi, T., Lasserre, G. 2003, The ecosystem approach to fisheries. FAO Fish. Tech. Pap. 443.

Gaspar P., Georges J.-Y., Fossette S., Lenoble A., Ferraroli S., Le Maho Y., 2006, Marine animal behaviour: neglecting ocean currents can lead us up the wrong track. Proc. R. Soc. 273, 26972702.

Gillanders B.M., 2002, Connectivity between juvenile and adult fish populations: do adults remain near their recruitment estuaries? Mar. Ecol. Prog. Ser. 240, 215-223.

Goetz F.W., MacKenzie S., 2008, Functional genomics with microarrays in fish biology and fisheries. Fish Fish. 9, 378-395.

Goodnight K.F., Queller D.C., 1999, Computer software for performing likelihood tests of pedigree relationship using genetic markers. Mol. Ecol. 8, 1231-1234.

Guinand B., Scribner K.T., 2003, Evaluation of methodology for detection of genetic bottlenecks: inferences from temporally replicated lake trout populations. C.R. Biol. 326, 61-67.

Gunn J., Block B.A., 2001, Advances in acoustic archival and satellite tagging of tunas. In: Block B.A. Stevens E.D. (Eds.) Tuna. Physiology ecology and evolution. Academic Press San Diego, pp. 167-224.

Hartl D.L., Clark A.G., 1997, Principles of population genetics. Sinauer Associates Sunderland MA, USA. 
Hauser L., Adcock G.J., Smith P.J., Ramirez J.H.B., Carvalho G.R., 2002, Loss of microsatellite diversity and low effective population size in an overexploited population of New Zealand snapper (Pagrus auratus). Proc. Nat. Acad. Sci. US 99, 11742-11747.

Hauser L., Carvalho G.R., 2008, Paradigm shifts in marine fisheries genetics: ugly hypotheses slain by beautiful facts. Fish Fish. 9, 333-362.

Hedgecock D., 1994, Does variance in reproductive success limit effective population sizes of marine organisms? In: Beaumont A.R. (Ed.) Genetics and Evolution of Aquatic Organisms. Chapman and Hall, pp. 122-134.

Hilborn R., Orensanz J., Parma A., 2005. Institutions incentives and the future of fisheries. Phil. Trans. R. Soc. B 360, 47-57.

Hilborn R., Quinn T.P., Schindler D.E., Rogers D.E., 2003, Biocomplexity and fisheries sustainability. Proc. Nat. Acad. Sci. US 100, 6564-6568.

Hilborn R. Walters C.J., 1992, Quantitative fisheries stock assessment. Choice dynamics and uncertainty. Chapman \& Hall NewYork.

Hoarau G., Boon E., Jongma D.N., Ferber S., Palsson J., Van der Veer H.W., Rijnsdorp A.D., Stam W.T., Olsen J.L., 2005, Low effective population size and evidence for inbreeding in an overexploited flatfish plaice (Pleuronectes platessa L.). Proc. R. Soc. B: Biol. Sci. 272, 497-503.

Hoie H. Folkvord A. Otterlei E., 2003, Effect of somatic and otolith growth rate on stable isotopic composition of early juvenile cod (Gadus morhua L.) otoliths. J. Exp. Mar. Biol. Ecol. 289, 41-58.

Hoie H., Otterlei E., Folkvord A., 2004, Temperature-dependent fractionation of stable oxygen isotopes in otoliths of juvenile cod (Gadus morhua L.). ICES J. Mar. Sci. 61, 243-251.

Holland K.N., Brill R.W., Chang R.K.C., Sibert J.R., Fournier D.A., 1992, Physiological and behavioural thermoregulation in bigeye tuna (Thunnus obesus). Nature 358, 410-412.

Holland K.N., Kajiura S.M., Itano D.G., Sibert J.R., 2001, Tagging techniques can elucidate the biology and exploitation of aggregated pelagic species. Am. Fish. Soc. Symp. 25, 211-218.

Hutchinson W.F., Carvahlo G.R., Rogers S.I., 2001, Marked genetic structuring in localised spawning populations of cod Gadus morhua in the North Sea and adjoining waters as revealed by microsatellites. Mar. Ecol. Progr. Ser. 223, 251-260.

Hutchinson W.F., van Oosterhout C., Rogers S.I., Carvalho G.R., 2003, Temporal analysis of archived samples indicates marked genetic changes in declining North Sea cod (Gadus morhua). Proc. R. Soc. B, Biol. Sci. 270, 2125-2132.

Ivany L.C., Patterson W.P., Lohmann K.C., 2000, Cooler winters as a possible cause of mass extinctions at the eocene/oligocene boundary. Nature 407, 887-890.

Kalish J.M., 1991, C-13 and O-18 isotopic disequilibria in fish otoliths - metabolic and kinetic effects. Mar. Ecol. Prog. Ser. 75, 191-203.

Kalish J.M., 1992, Formation of a stress-induced chemical check in fish otoliths. J. Exp. Mar. Biol. Ecol. 162, 265-277.

Kalman R., 1960, A new approach to linear filtering and prediction problems. Trans. Am. J. Bas. Eng. 82, 35-45.

Kennedy B.P., Blum J.D., Folt C.L., Nislow K.H., 2000, Using natural strontium isotopic signatures as fish markers: methodology and application. Can. J. Fish. Aquat. Sci. 57, 2280-2292.

Kitagawa T., Sartimbul A., Nakata H., Kimura S., Yamada H., Nitta A., 2006, The effect of water temperature on habitat use of young Pacific bluefin tuna Thunnus orientalis in the East China Sea. Fish. Sci. 72, 1166-1176.

Kooijman S.A.L.M., 2000, Dynamic energy and mass budgets in biological systems. Cambridge University Press.
Lacroix G.L., McCurdy P., 1996, Migratory behaviour of post-smolt Atlantic salmon during initial stages of seaward migration. J. Fish Biol. 49, 1086-1101.

Larkin P.A., 1996, Concepts and issues in marine ecosystem management. Rev. Fish Biol. Fish. 6, 139-164.

Lebreton J.D., Burnham K.P., Clobert J., Anderson D.R., 1992, Modelling survival and biological hypotheses using marked animals: a unified approach with case studies. Ecol. Monogr. 62, 67-118.

Lemaire C., Versini J., Bonhomme F., 2005, Maintenance of genetic differentiation across a transition zone in the sea: discordance between nuclear and cytoplasmic markers. J. Evol. Biol. 18, 70-80.

Lions J.L., 1971, Optimal control of systems governed by partial differential equations. Springer-Verlag.

Lukacs P.M., Burnham K.P., 2005, Review of capture-recapture methods applicable to noninvasive genetic sampling. Mol. Ecol. 14, 3909-3919.

Lutcavage M., Brill R.W., Skomal G.B., Chase B.C., Howey P.W., 1999, Results of pop-up satellite tagging of spawning size class fish in the Gulf of Maine: do North Atlantic bluefin tuna spawn in the mid-Atlantic? Can. J. Fish. Aquat. Sci. 56, 173-177.

Lynch M., Ritland K., 1999, Estimation of pairwise relatedness with molecular markers. Genetics 152, 1753-1766.

Miller C.R., Joyce P., Waits L.P., 2005, A new method for estimating the size of small populations from genetic mark-recapture data. Mol. Ecol. 14, 1991-2005.

Morin P.A., Luikart G., Wayne R.K., group T.S.W, 2004. SNPs in ecology evolution and conservation. Trends Ecol. Evol. 19, 208216.

Mowat G., Paetkau D., 2002, Estimating marten Martes americana population size using hair capture and genetic tagging. Wildlife Biol. 8, 201-209.

Musyl M.K., Brill R.W., Boggs C.H., Curran D.S., Kazama T.K., Seki M.P., 2003, Vertical movements of bigeye tuna (Thunnus obesus) associated with islands buoys and seamounts near the main Hawaiian Islands from archival tagging data. Fish. Oceanogr. 12, 152-169.

Neff B.D., 2001, Genetic paternity analysis and breeding success in bluegill sunfish (Lepomis macrochirus). J. Hered. 92, 111-119.

Nei M., 1973, Analysis of gene diversity in subdivided populations. Proc. Nat. Acad. Sci. US 70, 3321-3323.

Nei M., 1978, Estimation of average heterozygosity and genetic distance from small number of individuals. Genetics 89, 583-590.

Nielsen A., Sibert J.R., 2007, State-space model for light-based tracking of marine animals. Can. J. Fish. Aquat. Sci. 64, 1055-1068.

Nielsen E.E., Hansen M.M., Schmidt C., Meldrup D., Gronkjaer P., 2001, Fisheries: population of origin of Atlantic cod. Nature 413, 272.

Nielsen E.E., Nielsen P.H., Meldrup D., Hansen M.M., 2004, Genetic population structure of turbot (Scophthalmus maximus L.) supports the presence of multiple hybrid zones for marine fishes in the transition zone between the Baltic Sea and the North Sea. Mol. Ecol. 13, 585-595.

O’Reilly P.T., Canino M.F., Bailey K.M., Bentzen P., 2004, Inverse relationship between $F S T$ and microsatellite polymorphism in the marine fish walleye pollock (Theragra chalcogramma): implications for resolving weak population structure. Mol. Ecol. 13, 1799-1814.

Østergaard S., Hansen M.M., Loeschcke V., Nielsen E.E., 2003, Long-term temporal changes of genetic composition in brown trout (Salmo trutta L.) populations inhabiting an unstable environment. Mol. Ecol. 12, 3123-3135. 
Palsbøll P.J., 1999, Genetic tagging: contemporary molecular ecology. Biol. J. Linn. Soc. 68, 3-22.

Palsbøll P.J., Allen J., Bérubé M., Clapham P.J., Feddersen T.P., Hammondk P.S., Hudson R.R., Jørgensen H., Katona S., Larsen A.H., Larsen F., Lien J., Mattila D.K., Sigurjonnsson J., Sears R., Smith T., Sponer R., Stevick P., Øien N., 1997, Genetic tagging of humpback whales. Nature 388, 767-769.

Palsbøll P.J., Bérubé M., Allendorf F.W., 2007, Identification of management units using population genetic data. Trends Ecol. Evol. $22,11-16$.

Pauly D., Christensen V., Dalsgaard J., Froese R., Torres Jr F.C., 1998, Fishing down marine food webs. Science 279, 860-863.

Pérez-Ruzafa Á., González-Wangüiemert M., Lenfant P., Marcos C., García-Charton J.A., 2006, Effects of fishing protection on the genetic structure of fish populations. Biol. Conserv. 129, 244 255.

Petit E., Valiere N., 2006, Estimating population size with noninvasive capture-mark-recapture data. Conserv. Biol. 20, 1062-1073.

Pollock K.H., 2000, Capture-recapture models. Am. Stat. Assoc. 95, 293-296.

Porch C.E., 2005, The sustainability of Western Atlantic bluefin tuna: a warm blooded fish in a hot blooded fishery. Bull. Mar. Sci. 76, 363-384.

Prince E.D., Goodyear C.P., 2006, Hypoxia-based habitat compression of tropical pelagic fishes. Fish. Oceanogr. 15, 451-464.

Queller D.C., Goodnight K.F., 1989, Estimating relatedness using genetic markers. Evolution 43, 258-275.

Ramstad K.M., Woody C.A., Sage G.K., Allendorf F.W., 2004, Founding events influence genetic population structure of sockeye salmon (Oncorhynchus nerka) in Lake Clark Alaska. Mol. Ecol. 13, 277-290.

Ritland K., 1996, A marker-based method for inferences about quantitative inheritance in natural populations. Evolution 50, 10621073.

Ritland K., 2000, Marker-inferred relatedness as a tool for detecting heritability in nature. Mol. Ecol. 9, 1195-1204.

Romanek C.S., Gauldie R.W., 1996, A predictive model of otolith growth in fish based on the chemistry of the endolymph. Comp. Bioch. Physiol. Part A: Physiol. 114, 71-79.

Rooker J.R., Secor D.H., DeMetrio G., Schloesser R., Block B.A., Neilson J.D., 2008, Natal homing and connectivity in Atlantic bluefin tuna populations. Science 322, 742-744.

Rooker J.R., Secor D.H., Zdanowicz V.S., De Metrio G., Orsi-Relini L., 2003, Identification of Atlantic bluefin tuna (Thunnus thynnus) stocks from putative nurseries using otolith chemistry. Fish. Oceanogr. 12, 75-84.

Royer F., Fromentin J.-M., Gaspar P., 2005, A state/space model to derive bluefin tuna movement and habitat from archival tags. Oikos 109, 473-484.

Ruzzante D.E., Mariani S., Bekkevold D., André C., Mosegaard H., Clausen L.A., Dahlgren T.G., Hutchinson W.F., Hatfield E.M.C., Torstensen E., Brigham J., Simmonds E.J., Laikre L., Larsson L.C., Stet R.J.M., Ryman N., Carvahlo G.R., 2006, Biocomplexity in a highly migratory pelagic marine fish Atlantic herring. Proc. R. Soc. B: Biol. Sci. 273, 1459-1464.

Saenz-Agudelo P., Jones G.P., Thorrold S.R., Planes S., 2009, Estimating connectivity in marine populations: an empirical evaluation of assignment tests and parentage analysis under different gene flow scenarios. Mol. Ecol. 18, 1765-1776.

Schwartz M.K., Luikart G., Waples R.S., 2007, Genetic monitoring as a promising tool for conservation and management. Trends Ecol. Evol. 22, 25-33.

Secor D.H., 2000, Longevity and resilience of Chesapeake Bay striped bass. ICES J. Mar. Sci. 57, 808-815.

Sibert J.R., 2001, Electronic tagging and tracking in marine fisheries: introduction to the proceedings. In: Sibert J.R. Nielsen J.L. (Eds.) Electronic tagging and tracking in marine fisheries. Kluwer Academic Publishers Dordrecht, pp. 1-6.

Sibert J.R., Fournier D.A., 2001, Possible models for combining tracking data with conventional tagging data. In: Sibert J.R. Nielsen J.L. (Eds.) Electronic tagging and tracking in marine fisheries. Kluwer, Dordrecht, pp. 443-456.

Sibert J.R., Lutcavage M.E., Nielsen A., Brill R.W., Wilson S.G., 2006. Interannual variation in large-scale movement of Atlantic bluefin tuna (Thunnus thynnus) determined from pop-up satellite archival tags. Can. J. Fish. Aquat. Sci. 63, 2154-2166.

Sims D.W., Southall E.J., Humphries N.E., Hays G.C., Bradshaw C.J.A., Pitchford J.W., James A., Ahmed M.Z., Brierley A.S., Hindell M.A., Morritt D., Musyl M.K., Righton D., Shepard E.L.C., Wearmouth V.J., Wilson R.P., Witt M.J., Metcalfe J.D., 2008, Scaling laws of marine predator search behaviour. Nature 451, 1098-1102.

Slatkin M., 1995, A measure of population subdivision based on microsatellite allele frequencies. Genetics 139, 457-462.

Tsukamoto K., Nakai I., Tesch W.V., 1998, Do all freshwater eels migrate? Nature 396, 635-636.

Turner T.F., Wares J.P., Gold J.R., 2002, Genetic effective size is three orders of magnitude smaller than adult census size in an abundant estuarine-dependent marine fish (Sciaenops ocellatus). Genetics 162, 1329-1339.

Turrell W.R., 2004, The policy basis of the "ecosystem approach" to fisheries management. EuroGGOS publ. 21.

Voegeli F.A., Smale M.J., Webber D.M., Andrade Y., O'Dor R.K., 2001, Ultrasonic telemetry tracking and automated monitoring technology for sharks. Environ. Biol. Fish. 60, 267-281.

Wang J., 2002, An estimator for pairwise relatedness using molecular markers. Genetics 160, 1203-1215.

Waples R.S., 2002, Effective size of fluctuating salmon populations. Genetics 161, 783-791.

Waples R.S., Punt A.E., Cope J.M., 2008, Integrating genetic data into management of marine resources: how can we do it better? Fish Fish. 9, 423-449.

Willis J., 2008, Simulation model of universal law of school size distribution applied to southern bluefin tuna (Thunnus maccoyii) in the Great Australian Bight. Ecol. Model. 213, 33-44.

Woods J.G., Paetkau D., Lewis D., McLellan B.N., Proctor M., Strobeck C., 1999, Genetic tagging of free-ranging black and brown bears. Wildlife Soc. Bull. 27, 616-627.

Wright S., 1938, Size of population and breeding structure in relation to evolution. Science $87,430-431$.

Wright S., 1951, The genetical structure of populations. Ann. Eugen. 15, 323-354. 